\title{
REVIEW
}

\section{Derek Hastings}

\section{Catholicism and the Roots of Nazism: Religious Identity and National Socialism}

(Oxford and New York: Oxford University Press, 2010), hardcover, xv + 290 pp.

Reviewed by Eugene J. Fisher, Retired Associate Director for Ecumenical and Interreligious Relations, U.S. Conference of Catholic Bishops

This is an in-depth study of the connections between Catholics and the Catholic Church in Bavaria, especially Munich, and the Nazi movement. It begins with the rise of Nazism in 1919, continues through the Beerhall Putsch (Revolt) of 1923, and extends into the succeeding period of radical changes in Nazi ideology. While most readers will be aware of the antagonistic relationship between the Catholic Church and Hitler's Third Reich, the early Nazi movement emerged in a city and a region that was largely Catholic, with both supporters and opponents of National Socialism identifying themselves as Catholics.

Hastings begins his study with an evocation of the "peculiarities" of Munich's Catholic tradition (p. 17). Unlike in the rest of Germany, the Catholic community in Munich was notable for its independent streak. As the largest religious community, it had a relative openness to interconfessional cooperation and also a certain distance from the Catholic Center Party and its local branch, the Bavarian Volks Party. This relative independence from Rome rendered Bavarian Catholics more vulnerable to the appeals of right-wing nationalists than other German Catholics. Also, Munich Catholics were unlike Catholics in the rest of Germany and even throughout Europe, who had forged increasingly close ties to the Pope and supported Vatican resistance to secular states' efforts to control religious affairs since the early nineteenth century. In Munich, however, there was widespread Catholic resistance to so-called ultramontanism (from ultra montes, or "over the mountains" in Italy, where the Pope lived), as many felt they did not need such "foreign" assistance or guidance.

In Munich, the German volkische chauvinism, with its anti-ultramontanism, extended itself to "foreign" Jews, establishing a particularly fertile ground for what would become central to the ideology of the Nazi party. The sense of Nordic-Aryan superiority and imagery was blended with explicitly Catholic images and themes. The racial theories of Houston Chamberlain and Arthur deGobineau were popularly accepted, laying the groundwork for later experiments of forced sterilization of racially inferior elements within the superior, pure Aryan-German population.

Hastings throughout emphasizes the large number of Catholic priests and self-identified Catholic leaders attracted to and involved in these developments in Munich and southern Bavaria, and hence their active involvement in the development of the Nazi party in the region. He notes that all of this was in the context of a sense of "extreme crisis" (p. 47) that enveloped Munich after the First World War. There was a sense of vulnerability which allowed a "brief but brutal" take-over of the city in 1919 by a Soviet-style dictatorship in which Russian Jewish immigrants played a significant role. Reaction to the brutality of this short-lived regime further fanned the fires of 
antisemitism among many of the Catholic citizens of Munich. Hitler and other early Nazi leaders capitalized on these elements. They presented Nazism as the true Catholic party which could and would strongly resist foreign evils such as ultramontanism or the influence of the Jews, thus preserving the purity of Catholic Munich's race and religion.

Hastings shows the increasing success of Nazism in Munich along with its increasing stridency, and the shifting attitude of Church leaders. Whereas in the initial stages Catholic Church officials allowed, though did not encourage, the participation of Catholic priests in the movement, they eventually decided that the movement had become too extreme. Participation by priests was discouraged, and the most prominent supporters of Nazism were taken out of positions of authority within the diocese. This opposition culminated in a ban-issued "informally but no less definitively," Hastings writes-on attendance by Catholic priests at Nazi meetings just before the 1923 Putsch and a stern condemnation of antisemitism (p. 159).

Hitler, Hastings shows, began to see his success as foreordained. He saw the success of Mussolini in taking over Italy and felt he was destined to do so in Germany, gathering his forces for a great putsch that was to topple the Bavarian government and begin the takeover of all of Germany, as Mussolini had done in Italy. The Beerhall Putsch ended in violence and in the jailing of Hitler and his key henchmen. Hitler came out of jail believing himself to be the apocalyptic leader of a new world order and made the decision to join with other, similarly radical volkische groups in Germany to achieve his goal, increasingly seeing himself as the apocalyptic savior destined to establish a thousand-year Reich (Kingdom).

As Hastings convincingly argues, history shows that this tactic was successful within Germany. It also severed the last ties between Nazism and Catholicism in Germany, since Hitler's new allies were not only anti-Semites but anti-Catholics. The Catholic priests melted away and were replaced by Protestant ministers. Henceforth, the Nazi party and the Catholic Church, including the Catholics of Munich, were increasingly antagonistic, reflecting profound underlying differences between Catholicism and Nazism. Ironically, Hastings concludes, while Catholics in Munich had given Hitler his start, the only thing Catholic to remain in Nazism-as it rose to and took over power in Germany-was the sense of sacred (in Nazism's case, pagan) ceremony, illustrated in the famous Leni Riefenstahl film "Triumph of the Will."

This work is highly recommended for those interested in the history of the Christian churches, Nazism, and the Shoah. However, this reviewer might suggest a more nuanced title, such as "Catholics and the Roots of Nazism" rather than "Catholicism and the Roots of Nazism," given the distinctiveness, as Hastings himself emphasizes, of the Munich Catholic community and the growing opposition to Nazism by Church leaders in this period. 